\title{
Matrix metalloproteinase-13 is regulated by toll-like receptor-9 in colorectal cancer cells and mediates cellular migration
}

\author{
TIMO RATH $^{1}$, JULIA STÖCKLE ${ }^{1}$, MARTIN RODERFELD ${ }^{1}$, \\ ANNETTE TSCHUSCHNER ${ }^{1}$, JÜRGEN GRAF ${ }^{2,3}$ and ELKE ROEB ${ }^{1}$ \\ ${ }^{1}$ Department of Gastroenterology, Medical Clinic II, Justus-Liebig-University, Giessen; ${ }^{2}$ Deutsche Lufthansa AG, \\ Aero Medical Center, Frankfurt; ${ }^{3}$ Faculty of Medicine, Philipps-University Marburg, Marburg, Germany
}

Received December 8, 2010; Accepted March 14, 2011

DOI: $10.3892 / 01.2011 .276$

\begin{abstract}
Matrix metalloproteinases (MMPs) are associated with cancer cell invasion and metastasis, and are currently the most prominent proteases associated with tumorigenesis. In particular, abundant expression of MMP-13 in colorectal cancer $(\mathrm{CRC})$ is correlated with poor survival and the existence of distant metastasis. As suggested by recent in vitro studies, MMP-13 expression is regulated in a toll-like receptor (TLR)-9-dependent manner. In this study, we quantified the expression of MMP-13, TLR-9 and second messengers of the TLR signal transduction in CRC cells compared to colonic fibroblasts by RT-PCR. Furthermore, the effects of a selective TLR-9 stimulation on the expression of MMP-13 in CRC cells and colonic fibroblasts were analyzed. MMP-13 and TLR-9 as well as associated second messengers were simultaneously up-regulated in LS174 and SW620 cells compared to fibroblasts. Selective TLR-9 agonism with CpG oligonucleotides led to a significant increase in MMP-13 gene expression after $12 \mathrm{~h}$ of incubation in LS174 cells and after 12 and $24 \mathrm{~h}$ in SW620 cells, but not when using GpC oligonucleotides as a control substance. By contrast, MMP-13 gene expression remained unchanged in colonic fibroblasts following treatment with $\mathrm{CpG}$ or $\mathrm{GpC}$ oligonucleotides. The effects of selective MMP-13 inhibition on cellular migration were analyzed in Boyden chamber experiments. In the presence of 10 and $20 \mu \mathrm{M}$ of the specific MMP-13 inhibitor, CL-82198, migration of the LS174 cells was significantly reduced by 55 and 52\%, respectively, compared to untreated cells. In conclusion, the results of this study provide evidence of the TLR-9-dependent regulation of MMP-13 in CRC cells, but not in colonic fibroblasts. Since the specific inhibition of MMP-13 significantly reduces the migration of LS174 cells, selective MMP-13 inhibition may be a promising therapeutic strategy in CRC.
\end{abstract}

Correspondence to: Professor Elke Roeb, Department of Gastroenterology, Medical Clinic II, Justus Liebig University, Klinikstrasse 33, D-35392 Giessen, Germany

E-mail: elke.roeb@innere.med.uni-giessen.de

Key words: matrix metalloproteinases, toll-like receptors

\section{Introduction}

Colorectal cancer (CRC) is the second leading cause of death from cancer in industrialized nations, with 140,000 newly diagnosed CRC cases and 70,000 deaths from CRC in the United States in 2010 (1).

Cellular migration and invasion are critical parameters in the metastatic dissemination of cancer cells and the formation of distant metastasis is the major cause of death in cancer patients (2). Migratory cancer cells undergo major changes in their cell-cell and cell-matrix adhesion. The controlled degradation of the extracellular matrix (ECM) is a critical component for cell adhesion and cancer cell migration $(2,3)$. Matrix metalloproteinases (MMPs), a family of zinc metalloendopeptidases, are major proteolytic enzymes responsible for the degradation of ECM. MMPs have been associated with invasive tumor growth, metastasis and neovascularization in different types of tumors, such as CRC (4-6), and are therefore the most prominent proteases associated with tumorigenesis (7). In particular, MMP-7 and MMP-13 are expressed in a variety of tumor entities (8-12). Moreover, MMP-7 is associated with distant metastasis and adverse outcome in early CRC, whereas the expression of MMP-13 is correlated with poor survival and the existence of liver metastasis in CRC (13-16).

Recent in vitro studies in breast, brain and prostate cancer cells as well as in mesenchymal stem cells showed an increased expression of MMP-13 following treatment with 2'-deoxyribocytidine-phosphate-guanosine $(\mathrm{CpG})$ oligonucleotides as specific agonists of toll-like receptor-9 (TLR-9) (17-20). Furthermore, in vitro TLR-9 agonism leads to an enhanced MMP-13-mediated cellular invasion that can be inhibited following treatment with neutralizing anti-MMP-13 antibodies (18-20). Based on this evidence, we hypothesized that MMP-13 is regulated via TLR-9 in CRC cells in the same manner, and that the stimulation of TLR-9 in CRC cells results in an increased MMP-13 expression. The expression of MMP-13, TLR-9 and associated second messengers of the TLR signal transduction cascade in the CRC cell lines LS174 and SW620 was determined, and the effects of CpG oligonucleotides or non-stimulatory $\mathrm{GpC}$ control oligonucleotides on the expression of MMP-13 in these cells were analyzed. We further hypothesized that a selective MMP-13 inhibition 
Table I. SYBR-Green real-time qPCR primer sequences.

\begin{tabular}{llc}
\hline Gene & \multicolumn{1}{c}{ Primer sequence } & GenBank accession no \\
\hline Human 18 sRNA & Fw: GAT CAG ATA CCG TCG TAG TTC C & NR 003286 \\
Human TLR-9 & Rev: TAT CAA TCT GTC AAT CCT GTC C & \\
& Fw: CAT CTC AAC CTC AAG TGG AAC & NM 017442 \\
Human MyD88 & Rev: CTA GCA TCA GGA TGT TGG TAT & \\
Fuman IKK $\gamma$ & Rev: GTA TAT CTT GAA GCA GCA GCA G & NM 002468 \\
Human NF-kB & Fw: AGA ATA CGA CAA CCA CAT CAA G & \\
& Rev: CAG TTT GCT GTA CTC CCT CTG & NM 001145255 \\
Human MMP-13 & Fw: ATT ACA AAA CCA GCC TCT GT G & NM 001165412 \\
& Rev: TAT ACC CTG GAC CTG TAC TTC C & \\
& Fw: GCA GTC TTT CTT CGG CTT AG & NM 002427 \\
\end{tabular}

exhibits the potential to decreases the migration of CRC cells. Therefore, the effects of selective MMP-13 inhibition in LS174 cells in the Boyden chamber experiments were analyzed.

\section{Materials and methods}

Materials. Culture reagents were obtained from Sigma (Steinheim, Germany), Gibco (Eggenstein, Germany), Sarstedt (Berlin, Germany) or PAN Biotech (Aidenbach, Germany). All chemicals were purchased from Sigma, Pharmacia Biotech (Freiburg, Germany) or ICN (Meckenheim, Germany). Phosphorothioate-modified, human-specific CpG-ODNs (type C: 5'-TCG TCG TCG TTC GAA CGA CGT TGA T-3') and respective GpC-ODN negative controls were purchased from InVivoGen (San Diego, CA, USA) and dissolved in endotoxin-free sterile $\mathrm{dH}_{2} \mathrm{O}$ according to the manufacturer's instructions. A final concentration of $5 \mu \mathrm{M} \mathrm{CpG-ODN}$ or respective control was used in the cell culture experiments. The selective MMP-13 inhibitor CL-82198 was purchased from Enzo Life Sciences (Farmingdale, NY, USA) and dissolved in $\mathrm{dH}_{2} \mathrm{O}$ according to the manufacturer's instructions.

Cell culture. Human colon cancer cell lines SW620 (ATCC, CCL-227) and LS174 (ATCC, CL-188) were employed for this study. SW620 and LS174 cells were maintained in RPMI-1640 supplemented with $10 \%$ FCS, streptomycin (10 $\mathrm{mg} / \mathrm{l})$, and penicillin (10 U/l). CCD18 fibroblasts from human colon (ECACC, CCD-18Co) were cultured in Eagle's minimal essential medium with $20 \%$ FCS, $1 \%$ glutamine, streptomycin $(10 \mathrm{mg} / \mathrm{l})$ and penicillin $(10 \mathrm{U} / \mathrm{l})$. Cells were grown in 5\% $\mathrm{CO}_{2}$ at $37^{\circ} \mathrm{C}$ in a water-saturated atmosphere. One day prior to experiments, the cells were seeded to provide a final cell density of $60-70 \%$ confluence.

RNA purification, cDNA synthesis and RT-PCR for MMP analyses. Total cellular RNA was extracted from LS174, SW620 and CCD18 cells using the RNeasy kit (Qiagen, Hilden, Germany) according to the manufacturer's instructions. First-strand cDNA was synthesized from DNA-free total RNA using oligo-dT primers and the first-strand cDNA synthesis kit for RT-PCR (Roche Diagnostics, Mannheim, Germany). RNA ( $1 \mu \mathrm{g})$ was utilized for the reverse transcriptase reaction according to the manufacturer's instructions. Real-time PCR was performed using a Platinum SYBR-Green qPCR kit (Invitrogen, Karlsruhe, Germany) according to the manufacturer's instructions. Real-time PCR of each genespecific primer pair was optimized prior to the experiment to confirm the absence of any non-specific amplification product. Primers were purchased from Eurofins (Ebersberg, Germany). Primer sequences are shown in Table I.

qRT-PCR was performed on the Mx3000P (Stratagene, La Jolla, CA, USA) using 3-stage program parameters as follows: i) $10 \mathrm{~min}$ at $96^{\circ} \mathrm{C}$; ii) 40 cycles of $10 \mathrm{sec}$ at $95^{\circ} \mathrm{C}, 30 \mathrm{sec}$ at $57^{\circ} \mathrm{C}$ and $30 \mathrm{sec}$ at $73^{\circ} \mathrm{C}$; iii) $10 \mathrm{~min}$ at $73^{\circ} \mathrm{C}$. The specificity of the PCR was confirmed by examination of the dissociation reaction plot subsequent to qRT-PCR. PCR products were separated on a $1.5 \%$ TAE agarose gel and visualized by staining with ethidium bromide to confirm the appearance of a single band of the correct molecular size. qRT-PCR data were analyzed using the $\Delta \Delta \mathrm{Ct}$ model (21).

Boyden chamber experiments. Transwell $8-\mu \mathrm{m}$ pore membrane inserts (18-mm standard PCTE filters; Neuro Probe, Gaithersburg, MD, USA) were activated for $20 \mathrm{~min}$ at $50^{\circ} \mathrm{C}$ with $0.5 \%$ acetic acid. After drying $\left(100^{\circ} \mathrm{C}, 1 \mathrm{~h}\right.$ on Whatman paper) the inserts were placed in a blind well chemotaxis chamber (Neuro Probe). The lower compartment was filled with FCS-containing medium as a chemoattractant. Prior to seeding, the cells were cultured in FCS-free medium for $24 \mathrm{~h}$, detached by trypsin treatment and rinsed with FCS-free medium. Cells $\left(2 \times 10^{5}\right)$, with or without CL-82198 or BSA as a reference protein, were added to the upper chamber. Chambers were placed in a humified tissue incubator containing $5 \% \mathrm{CO}_{2}$ for $24 \mathrm{~h}$ at $37^{\circ} \mathrm{C}$. Cells on the upper surface of the transwell inserts were removed using a cotton swab and those on the lower surface of the membranes were fixed with $10 \%$ methanol and stained with crystal violet. Membranes were rinsed with deionized water, dried and examined using light microscopy. The number of migrated cells in five optical fields (magnification, $\mathrm{x} 400$ ) was averaged. 
A LS174 cells

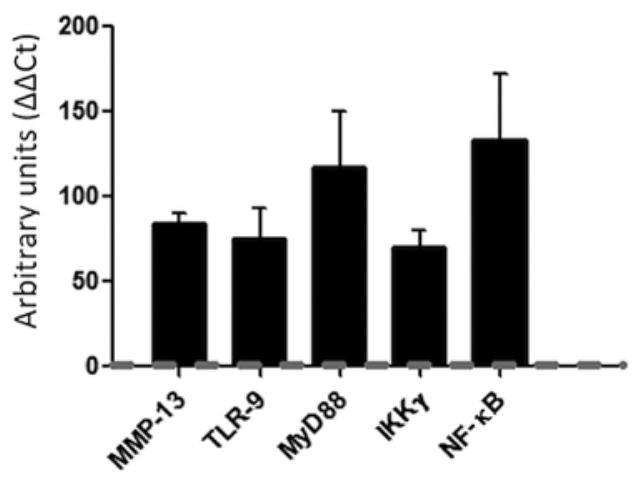

B SW620 cells

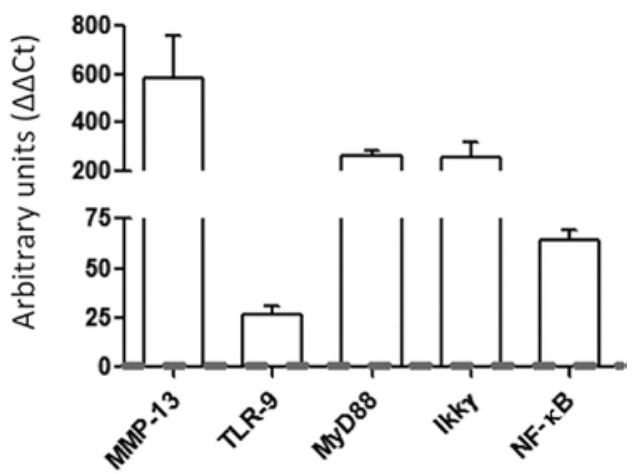

Figure 1. Enhanced expression of MMP-13, TLR-9 and second messengers of the TLR signal transduction cascade in CRC cells. (A) LS174 cells (black bars) showed an enhanced gene transcription of MMP-13 (84-fold, $\mathrm{p}=0.016$ ) and TLR-9 (75-fold, $\mathrm{p}=0.016$ ), and also of MyD88 (117-fold, $\mathrm{p}=0.016$ ), IKK $\gamma$ ( 70 -fold, $\mathrm{p}=0.036)$ and NF- $\mathrm{KB}(133$-fold, $\mathrm{p}=0.036)$ as second messengers and effectors of the signal transduction cascade. (B) In SW620 cells, the expression of MMP-13, TLR-9 and associated second messengers was also increased (MMP-13: 587-fold, $\mathrm{p}=0.008$; TLR-9: 26-fold, $\mathrm{p}=0.004$; MyD88: 264-fold, $\mathrm{p}=0.036$; IKK $\gamma$ : 255-fold, $\mathrm{p}=0.008$; NF-кB: 64-fold, $\mathrm{p}=0.036$ ). Abundant expression levels in CRC were related to the respective gene expression in colon fibroblasts, which were set as a reference (grey dashed line). The values shown are the mean \pm SEM.

Statistical analysis. Differences between groups were assessed using the Mann-Whitney U-Test. $\mathrm{P}<0.05$ was considered to be statistically significant. Statistical analysis was performed with SPSS 17.0 (SPSS Inc., Chicago, IL, USA). The values are shown as the mean \pm SEM.

\section{Results}

Expression of MMP-13, TLR-9 and associated second messengers of the TLR signal transduction cascade. The gene expression of MMP-13 and TLR-9 was assessed by quantitative RT-PCR in LS174, SW620 and CCD18 cells. Furthermore, the expression levels of MyD88 and IKK $\gamma$ as second messengers and NF- $\mathrm{B}$ as the main effector of TLR-9 signaling were quantified. The results were compared against 18s RNA, which served as a housekeeping gene. To calculate the abundant expression in CRC cells, the expression of the respective genes in colonic fibroblasts was set as a reference. Determination of gene expression by RT-PCR was performed from six individually growing culture plates for each cell line $(n=6)$.

In LS174 cells, MMP-13 gene expression was significantly enhanced compared to human colon fibroblasts (84-fold, $\mathrm{p}=0.016$ ). Concomitantly, LS174 cells exhibited significantly enhanced mRNA levels of TLR-9, MyD88, IKK $\gamma$ and NF- $\mathrm{BB}$ (Fig. 1A; TLR-9: 75-fold, $\mathrm{p}=0.016$; MyD88: 117-fold, $\mathrm{p}=0.016$; IKK $\gamma$ : 70 -fold, $\mathrm{p}=0.036$ and $\mathrm{NF}-\kappa \mathrm{B}$ : 133 -fold, $\mathrm{p}=0.036$ ).

Similarly in SW620 cells, we observed an increased gene expression of MMP-13, TLR-9 and associated second messengers of the TLR signal transduction cascade (Fig. 1B; MMP-13: 587-fold, $\mathrm{p}=0.008$; TLR-9: 26-fold, $\mathrm{p}=0.004$; MyD88: 264-fold, $\mathrm{p}=0.036$; IKK $\gamma$ : 255-fold, $\mathrm{p}=0.008$ and NF- $\kappa$ B: 64-fold, $\mathrm{p}=0.036$ ).

TLR-9 agonists induced MMP-13 expression in human CRC cells, but not in colon fibroblasts. Based on our observation of a simultaneous increase in MMP-13 and TLR-9 gene expression in CRC cells and on recent reports of a TLR-9-dependent regulation of MMP-13 (17-20), we hypothesized that TLR-9 stimulation leads to an enhanced MMP-13 secretion in CRC cells. We used $\mathrm{CpG}$ motif containing unmethylated oligodeoxynucleotides (CpG-ODN) as well-characterized TLR-9 ligands mimicking the actions of bacterial DNA (22-24), and non-stimulatory GpC-ODN as a control substance. Cells treated with $\mathrm{CpG}-\mathrm{ODN}$ or GpC-ODN are indicated by CpG-ODN-positive and $\mathrm{CpG}-\mathrm{ODN}$-negative, respectively, in Fig. 2. Experiments were performed in triplicate. In LS174 cells treated with $5 \mu \mathrm{M}$ of CpG-ODN, MMP-13 gene expression was enhanced 3.6-fold after $12 \mathrm{~h}$ in relation to the baseline expression at $0 \mathrm{~h}$, and increased further to 3.9-fold after $24 \mathrm{~h}$, although the latter result did not reach the level of statistical significance (Fig. 2; CpG-ODN-positive: 12 h: 3.6-fold increase, $\mathrm{p}=0.049$ and $24 \mathrm{~h}$ : 3.9-fold increase, $\mathrm{p}=0.12$ ). By contrast, MMP-13 expression in LS174 cells treated with $5 \mu \mathrm{M}$ control substance, which contained $\mathrm{GpC}$ dinucleotides instead of $\mathrm{CpGs}$, did not significantly change in relation to its baseline expression after 12 and $24 \mathrm{~h}$ of culture (Fig. 2; CpG-ODN-negative: $12 \mathrm{~h}$ : factor 0.99, $\mathrm{p}=0.83$ and $24 \mathrm{~h}$ : factor $1.98, \mathrm{p}=0.08$ ).

A similar result was obtained in SW620 cells: in the presence of $5 \mu \mathrm{M}$ of CpG-ODN, MMP-13 gene expression was significantly increased from the baseline expression by a factor of 2.7 after $12 \mathrm{~h}(\mathrm{p}=0.049)$ and by a factor of 2.3 after $24 \mathrm{~h}(\mathrm{p}=0.049)$, whereas MMP-13 mRNA was not significantly altered in SW620 cells treated with the control substance (Fig. 2; CpG-ODN-negative: 12 h: factor 1.8, p=0.275; 24 h: factor $0.8 ; \mathrm{p}=0.827$ ). In human colon fibroblasts, however, MMP-13 gene expression remained unchanged after 12 and $24 \mathrm{~h}$ irrespective of the presence of CpG-ODN or GpC-ODN (Fig. 2; CpG-ODN-positive: $12 \mathrm{~h}$ : factor 1.36, $\mathrm{p}=0.827 ; 24 \mathrm{~h}$ : factor $0.25, \mathrm{p}=0.513$; CpG-ODN-negative: $12 \mathrm{~h}$ : factor 0.67 , $\mathrm{p}=0.827 ; 24 \mathrm{~h}$ : factor $0.52, \mathrm{p}=0.827$ ).

Specific MMP-13 inhibition reduces the migration of LS174 cells. To investigate whether the inhibition of MMP-13 affects the migration of colon carcinoma cells, we examined the motility of LS174 cells in Boyden chamber experiments in the presence or absence of the selective MMP-13 inhibitor CL-82198 or BSA as a reference protein. For these analyses, 
A
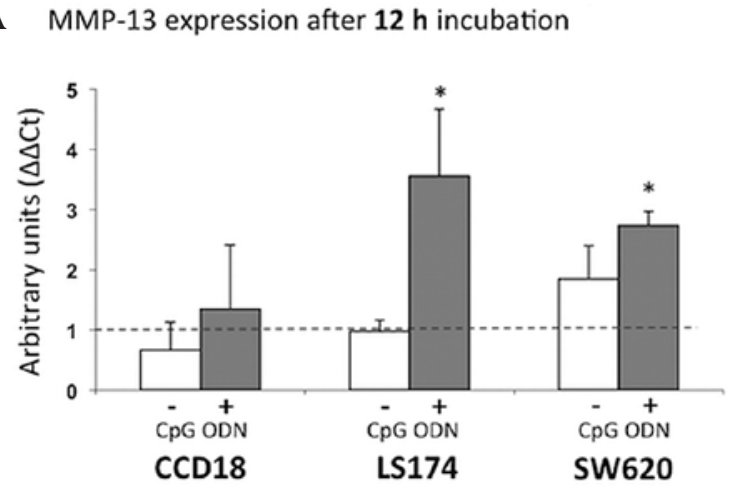

B $\mathrm{MMP}-13$ expression after $\mathbf{2 4} \mathrm{h}$ incubation

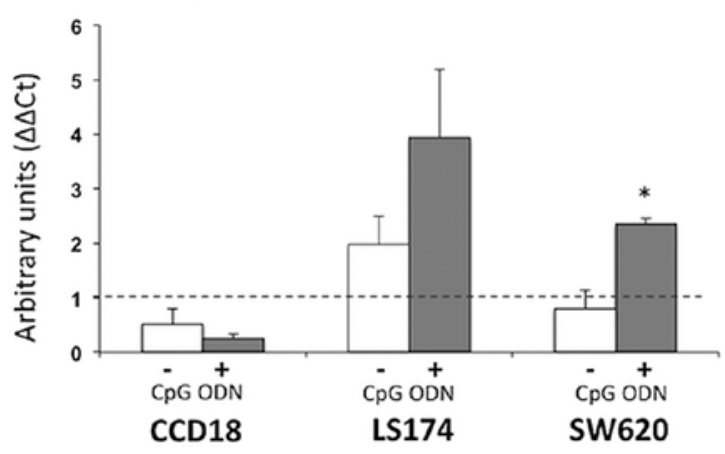

Figure 2. TLR-9 agonism leads to increased MMP-13 gene expression in CRC cells, but not in human fibroblasts. Cells were treated with CpG oligonucleotides as a TLR-9 ligand (CpG-ODN-positive) or non-stimulatory GpC-ODN (CpG-ODN-negative). MMP-13 gene expression was measured after (A) 12 h and (B) $24 \mathrm{~h}$, and in relation to the respective baseline expression at $0 \mathrm{~h}$ (indicated by the dashed line). In LS174 cells treated with $5 \mu \mathrm{M}$ of CpG-ODN, MMP-13 gene expression was enhanced 3.6-fold after $12 \mathrm{~h}(\mathrm{CpG}-\mathrm{ODN}$-positive: $\mathrm{p}=0.049)$ and increased further to 3.9 fold after $24 \mathrm{~h}$ in relation to its baseline expression at $0 \mathrm{~h}$, although the latter results did not reach the level of statistical significance (CpG-ODN-positive: $\mathrm{p}=0.12$ ). By contrast, MMP-13 expression in LS174 cells treated with $5 \mu \mathrm{M}$ GpC-ODN did not significantly change in relation to its baseline expression after 12 and $24 \mathrm{~h}$ of culture (CpG-ODN-negative: 12 h: factor $0.99, \mathrm{p}=0.83 ; 24 \mathrm{~h}$ : factor $1.98, \mathrm{p}=0.08$ ). In SW620 cells, the presence of $5 \mu \mathrm{M}$ CpG-ODN increased MMP-13 gene expression by a factor of 2.7 after $12 \mathrm{~h}$ (CpG-ODN-positive: $\mathrm{p}=0.049)$ and by a factor of 2.3 after $24 \mathrm{~h}$ (CpG-ODN-positive: p=0.049), whereas MMP-13 mRNA was not significantly altered in SW620 cells treated with GpC-ODN (CpG-ODN-negative: 12 h: factor $1.8, \mathrm{p}=0.275 ; 24$ h: factor 0.8 ; $\mathrm{p}=0.827$ ). In human colon fibroblasts (CCD18), however, MMP-13 gene expression remained unchanged after 12 and $24 \mathrm{~h}$, irrespective of the presence of CpG-ODN or GpC-ODN (12 h: CpG-ODN-positive: $1.36-$ fold, $\mathrm{p}=0.827$; CpG-ODN-negative: 0.67, $\mathrm{p}=0.827 ; 24$ h: CpG-ODN-positive: 0.25 -fold, $\mathrm{p}=0.513$; CpG-ODN-negative: 0.52 -fold, $\mathrm{p}=0.827$ ). Experiments were performed in triplicate $(n=3)$ for each group. The values shown are the mean \pm SEM.

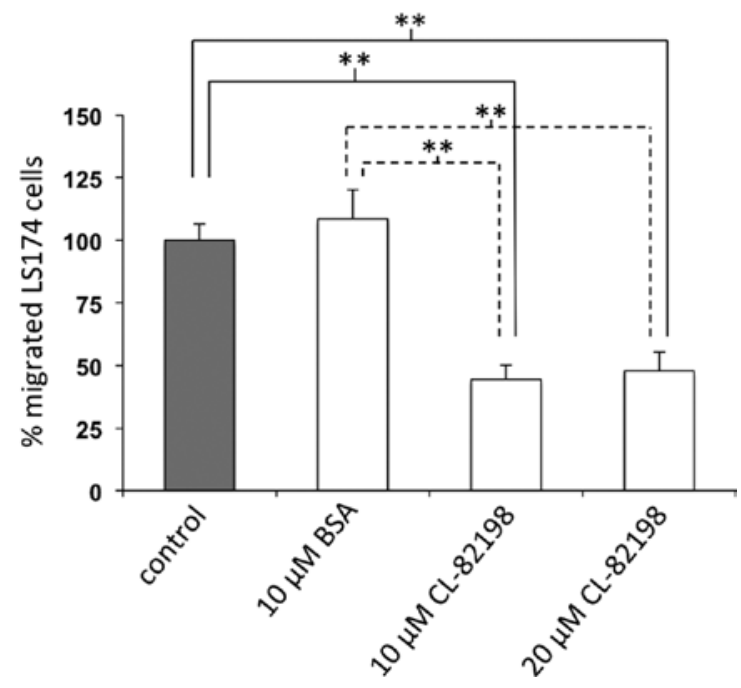

Figure 3. Specific inhibition of MMP-13 significantly reduces the migration of LS174 cells. LS174 cells were incubated in the presence of 10 and $20 \mu \mathrm{M}$ CL-82198 or $10 \mu \mathrm{M}$ BSA. Migration was assessed after $24 \mathrm{~h}$ of incubation with the respective substances. Compared to untreated or BSA-treated cells, $10 \mu \mathrm{M}$ of CL-82198 as a specific MMP-13 inhibitor reduced LS174 cell migration to $45 \pm 5.6 \%(\mathrm{p}=0.004)$ or $41 \pm 5.1 \%(\mathrm{p}=0.004)$. Increasing the concentration of CL-82198 to $20 \mu \mathrm{M}$ did not further reduce the migration of LS174 cells compared to the concentration of $10 \mu \mathrm{M}(\mathrm{p}=0.818)$. Migration of the LS174 was unchanged between the untreated cells and cells treated with $10 \mu \mathrm{M}$ BSA as a reference protein $(\mathrm{p}=0.818)$. Experiments were carried out with $\mathrm{n}=6$ for each substance. Results are shown as the mean \pm SEM.

we focused on LS174 cells as these cells are primary tumor cells, whereas SW620 cells are metastasis-derived. CL-82198 binds to the S1' pocket of MMP-13 leading to $89 \%$ enzyme inhibition at a concentration of $10 \mu \mathrm{g} / \mathrm{ml}$ (25). Following a 24-h incubation, migrated cells on the underside of the membrane were counted. Migration experiments were performed with $\mathrm{n}=6$ per group.
Compared to the untreated cells, the addition of the specific MMP-13 inhibitor CL-82198 at a concentration of $10 \mu \mathrm{M}$ resulted in a $45 \pm 5.6 \%$ reduction in the migration of LS174 cells $(\mathrm{p}=0.004)$. When compared to BSA-treated cells, LS174 cell migration was significantly reduced as well in the presence of $10 \mu \mathrm{M}$ CL-82198 (41 $\pm 5.1 \%, \mathrm{p}=0.004)$. Similarly, at a concentration of $20 \mu \mathrm{M}$ CL-82198, LS174 cell migration was reduced compared to the untreated $(48 \pm 7.3 \%, \mathrm{p}=0.004)$ or BSA-treated cells $(44 \pm 6.7 \%, \mathrm{p}=0.002)$, although this migration was not further reduced compared to LS174 cells treated with $10 \mu \mathrm{M}$ CL-82198 ( $\mathrm{p}=0.818)$. Cellular migration was unchanged between the untreated and BSA-treated LS174 cells $(\mathrm{p}=0.818)$ (Fig. 3).

\section{Discussion}

Mounting evidence supports the hypothesis that extracellular proteinases, such as MMPs, mediate a number of changes in the microenvironment during tumor progression and metastasis. Tumor metastasis is generally considered to be a multistep process involving attachment to ECM, local matrix proteolysis and tumor cell migration (26-28). Although MMPs play diverse biological roles in cancer, a pivotal role is the degradation and remodeling of ECM, thereby paving the way through the peripheral tissue for invasion and metastasis (5-7,29). Among others, MMP-13 is expressed in a variety of tumor entities $(8,9,30,31)$ such as CRC (10-12) and adenomatous polyps (32). Furthermore, MMP-13 expression in CRC is correlated with poor survival (14) and the existence of liver metastasis (16).

Recent in vitro studies have shown that MMP-13 expression is regulated via TLR-9 (17-20). Furthermore, treatment of TLR-9-expressing cancer cells of various origin, such as breast, brain and prostate, and mesenchymal stem cells with TLR-9 ligands stimulates their invasive cell behaviour in a 
MMP-13-dependent manner (17-20). TLRs are evolutionarily well-conserved transmembrane proteins that identify other conserved structures, particularly microbial components. TLRs are present in almost all multi-cellular organisms (33). The mammalian TLR family constitutes 11 members, each of which identifies a different, pathogen-derived ligand. TLR-9 responds to unmethylated CpG DNA motifs that are frequently present in bacteria and viruses, but are rare in mammalian cells (22-24). Mounting evidence indicates that TLR-9 expression is not confined to cells of the immune system, as TLR-9 expression has been detected in astrocytes, mesenchymal cells and in various normal epithelial and cancer cells, including breast, brain, lung and gastric cancer cells (17,19,34-38).

Against this background, we aimed to analyze whether MMP-13 expression is also regulated by TLR-9 in CRC. In a series of experiments, we studied the gene expression of MMP-13, TLR-9 and downstream messengers of the TLR signal transduction cascade in LS174 and SW620 cells, and compared this expression to the respective gene expression in human colonic fibroblasts. Using this approa, we demonstrated that the expression levels of MMP-13 and TLR-9 and associated second messengers are simultaneously increased in LS174 and SW620 cells. To determine the TLR-9-dependent expression of MMP-13, we selectively stimulated TLR-9 using $\mathrm{CpG}$ oligonucleotides and quantified the MMP-13 gene expression after 12 and $24 \mathrm{~h}$ compared to the baseline expression at $0 \mathrm{~h}$. Our findings provide clear evidence that TLR-9 agonism with $\mathrm{CpG}$ oligonucleotides leads to an enhanced MMP-13 gene expression in LS174 and SW620 cells. By contrast, $\mathrm{GpC}$ oligonucleotides as a control substance failed to induce MMP-13 gene expression in these two cell lines. Notably, although benign human colonic fibroblasts expressed TLR-9 (as confirmed within our RT-PCR studies), they did not exhibit any TLR-9-dependent expression of MMP-13, suggesting a carcinoma-specific mechanism. Finally, we showed that the selective inhibition of MMP-13 via a synthetic inhibitor (CL-82198) reduced the migration of CRC cells by $56 \%$.

CL-82198 was developed in NMR studies and binds to the entire S1' pocket of MMP-13, which is the basis for its selectivity towards MMP-13 and the lack of inhibitory activities against other MMPs (25). Furthermore, CL-82198 was shown to provide an enzyme inhibition of $89 \%$ at a concentration of $10 \mu \mathrm{g} / \mathrm{ml}(25)$. This inhibitory ability of almost complete MMP-13 inhibition at a relatively low concentration is consistent with our observations, since we were unable to detect a further reduction of cellular migration when the concentration of CL-82198 was increased from 10 to $20 \mu \mathrm{M} \mathrm{\kappa}$.

MMP inhibition as a therapeutic target in cancer treatment is an area of intense investigation. The first drug development programs, based on compelling evidence of MMP-mediated angiogenesis and metastasis in different tumor models, were initiated approximately 25 years ago and eventually led to small-molecule metalloproteinase inhibitor (MPI) drugs in phase III clinical trials. The effects of MPIs in these trials turned out to be disappointing as they failed to increase the survival of cancer patients (39). However, a number of these trials were conducted on patients with advanced stages of cancer, whereas in murine tumor models MMP inhibition was generally initiated at an early stage of the disease and maintained throughout tumor progression (39). Consequently, whether MPIs may have been more effective if used at an earlier stage of the disease remains to be determined. Furthermore, many of the utilized MPIs, such as marimastat or batimastat, were broad-spectrum MMP inhibitors. Given the growing evidence of an essential role of a number of MMPs in various physiological functions, such as growth, cytokine signaling, innate immunity (40) and inflammatory conditions (40-42), it seems inevitable to selectively inhibit single MMPs in further trials to comprehensively evaluate their specific therapeutic potential.

In conclusion, the results of this study provide evidence of a TLR-9-dependent regulation of MMP-13 in CRC cells, but not in human colonic fibroblasts, suggesting a carcinomaspecific mechanism. It was further demonstrated that the specific inhibition of MMP-13 reduces the migration of CRC cells. Therefore, selective MMP-13 inhibition may be a promising therapeutic strategy in CRC.

\section{Acknowledgements}

This study was supported by grants from the Deutsche Forschungsgemeinschaft (RO 957/7-1 and RO 957/8-1) and from the ZooMAP (Bundesministerium für Bildung und Forschung, BMBF). Dr Timo Rath has received grants for young researchers ('Anschubfinanzierung') from the JustusLiebig-University Giessen.

\section{References}

1. Jemal A, Siegel R, Xu J and Ward E: Cancer statistics. CA Cancer J Clin 60: 277-300, 2010.

2. Yilmaz $\mathrm{M}$ and Christofori G: Mechanisms of motility in metastasizing cells. Mol Cancer Res 8: 629-642, 2010.

3. Shapiro SD: Matrix metalloproteinase degradation of extracellular matrix: biological consequences. Curr Opin Cell Biol 10: 602-608, 1998.

4. Decock J, Paridaens R and Ye S: Genetic polymorphisms of matrix metalloproteinases in lung, breast and colorectal cancer. Clin Genet 73: 197-211, 2008.

5. Egeblad M and Werb Z: New functions for the matrix metalloproteinases in cancer progression. Nat Rev Cancer 2: 161-174, 2002.

6. Fingleton B: Matrix metalloproteinases: roles in cancer and metastasis. Front Biosci 11: 479-491, 2006.

7. Kessenbrock K, Plaks V and Werb Z: Matrix metalloproteinases: regulators of the tumor microenvironment. Cell 141: 52-67, 2010.

8. Airola K, Karonen T, Vaalamo M, et al: Expression of collagenases- 1 and -3 and their inhibitors TIMP- 1 and -3 correlates with the level of invasion in malignant melanomas. Br J Cancer 80: 733-743, 1999.

9. Heppner KJ, Matrisian LM, Jensen RA and Rodgers WH: Expression of most matrix metalloproteinase family members in breast cancer represents a tumor-induced host response. Am J Pathol 149: 273-282, 1996.

10. Hilska M, Roberts PJ, Collan YU, et al: Prognostic significance of matrix metalloproteinases-1, $-2,-7$ and -13 and tissue inhibitors of metalloproteinases-1, $-2,-3$ and -4 in colorectal cancer. Int J Cancer 121: 714-723, 2007.

11. Mori D, Nakafusa Y, Miyazaki K and Tokunaga O: Differential expression of Janus kinase 3 (JAK3), matrix metalloproteinase 13 (MMP13), heat shock protein 60 (HSP60), and mouse double minute 2 (MDM2) in human colorectal cancer progression using human cancer cDNA microarrays. Pathol Res Pract 201: 777-789, 2005.

12. Roeb E, Arndt M, Jansen B, Schumpelick V and Matern S: Simultaneous determination of matrix metalloproteinase (MMP)-7, MMP-1, -3, and -13 gene expression by multiplex PCR in colorectal carcinomas. Int J Colorectal Dis 19: 518-524, 2004. 
13. Fang YJ, Lu ZH, Wang GQ, et al: Elevated expressions of MMP7, TROP2, and survivin are associated with survival, disease recurrence, and liver metastasis of colon cancer. Int J Colorectal Dis 24: 875-884, 2009.

14. Leeman MF, McKay JA and Murray GI: Matrix metalloproteinase 13 activity is associated with poor prognosis in colorectal cancer. J Clin Pathol 55: 758-762, 2002.

15. Masaki T, Matsuoka H, Sugiyama M, et al: Matrilysin (MMP-7) as a significant determinant of malignant potential of early invasive colorectal carcinomas. Br J Cancer 84: 1317-1321, 2001

16. Yamada $\mathrm{T}$, Oshima $\mathrm{T}$, Yoshihara $\mathrm{K}$, et al: Overexpression of MMP-13 gene in colorectal cancer with liver metastasis. Anticancer Res 30: 2693-2699, 2010.

17. Ilvesaro JM, Merrell MA, Li L, et al: Toll-like receptor 9 mediates $\mathrm{CpG}$ oligonucleotide-induced cellular invasion. Mol Cancer Res 6: 1534-1543, 2008.

18. Ilvesaro JM, Merrell MA, Swain TM, et al: Toll like receptor-9 agonists stimulate prostate cancer invasion in vitro. Prostate 67: 774-781, 2007.

19. Merrell MA, Ilvesaro JM, Lehtonen N, et al: Toll-like receptor 9 agonists promote cellular invasion by increasing matrix metalloproteinase activity. Mol Cancer Res 4: 437-447, 2006.

20. Nurmenniemi S, Kuvaja P, Lehtonen S, et al: Toll-like receptor 9 ligands enhance mesenchymal stem cell invasion and expression of matrix metalloprotease-13. Exp Cell Res 316: 2676-2682, 2010.

21. Pfaffl MW: A new mathematical model for relative quantification in real-time RT-PCR. Nucleic Acids Res 29: e45, 2001.

22. Hemmi H, Takeuchi O, Kawai T, et al: A Toll-like receptor recognizes bacterial DNA. Nature 408: 740-745, 2000.

23. Latz E, Visintin A, Espevik T and Golenbock DT: Mechanisms of TLR9 activation. J Endotoxin Res 10: 406-412, 2004.

24. Takeshita F, Gursel I, Ishii KJ, Suzuki K, Gursel M and Klinman DM: Signal transduction pathways mediated by the interaction of $\mathrm{CpG}$ DNA with Toll-like receptor 9. Semin Immunol 16: 17-22, 2004.

25. Chen JM, Nelson FC, Levin JI, et al: Structure-based design of a novel, potent, and selective inhibitor for MMP-13 utilizing NMR spectroscopy and computer-aided molecular desing. J Am Chem Soc 122: 9648-9654, 2000

26. Koblinski JE, Ahram M and Sloane BF: Unraveling the role of proteases in cancer. Clin Chim Acta 291: 113-135, 2000.

27. Nelson AR, Fingleton B, Rothenberg ML and Matrisian LM: Matrix metalloproteinases: biologic activity and clinical implications. J Clin Oncol 18: 1135-1149, 2000.

28. Stetler-Stevenson WG, Aznavoorian S and Liotta LA: Tumor cell interactions with the extracellular matrix during invasion and metastasis. Annu Rev Cell Biol 9: 541-573, 1993.
29. Deryugina EI and Quigley JP: Matrix metalloproteinases and tumor metastasis. Cancer Metastasis Rev 25: 9-34, 2006.

30. Inoue A, Takahashi H, Harada H, et al: Cancer stem-like cells of glioblastoma characteristically express MMP-13 and display highly invasive activity. Int J Oncol 37: 1121-1131, 2010.

31. Yong HY, Kim IY, Kim JS and Moon A: ErbB2-enhanced invasiveness of H-Ras MCF10A breast cells requires MMP-13 and UPA upregulation via p38 MAPK signaling. Int J Oncol 36: 501-507, 2010.

32. Rath T, Roderfeld M, Graf J, et al: Enhanced expression of MMP-7 and MMP-13 in inflammatory bowel disease: a precancerous potential? Inflamm Bowel Dis 12: 1025-1035, 2006.

33. Kawai T and Akira S: The role of pattern-recognition receptors in innate immunity: update on Toll-like receptors. Nat Immunol 11: 373-384, 2010.

34. Bowman CC, Rasley A, Tranguch SL and Marriott I: Cultured astrocytes express toll-like receptors for bacterial products. Glia 43: 281-291, 2003.

35. Droemann D, Albrecht D, Gerdes J, et al: Human lung cancer cells express functionally active Toll-like receptor 9. Respir Res 6: 1,2005.

36. Platz J, Beisswenger C, Dalpke A, et al: Microbial DNA induces a host defense reaction of human respiratory epithelial cells. J Immunol 173: 1219-1223, 2004.

37. Schmausser B, Andrulis M, Endrich S, et al: Expression and subcellular distribution of toll-like receptors TLR4, TLR5 and TLR9 on the gastric epithelium in Helicobacter pylori infection. Clin Exp Immunol 136: 521-526, 2004.

38. Schmausser B, Andrulis M, Endrich S, Muller-Hermelink HK and Eck M: Toll-like receptors TLR4, TLR5 and TLR9 on gastric carcinoma cells: an implication for interaction with Helicobacter pylori. Int J Med Microbiol 295: 179-185, 2005.

39. Coussens LM, Fingleton B and Matrisian LM: Matrix metalloproteinase inhibitors and cancer: trials and tribulations. Science 295: 2387-2392, 2002.

40. Parks WC, Wilson CL and Lopez-Boado YS: Matrix metalloproteinases as modulators of inflammation and innate immunity. Nat Rev Immunol 4: 617-629, 2004.

41. Rath T, Roderfeld M, Graf J and Roeb E: [Matrix metalloproteinases in inflammatory bowel disease - from basic research to clinical significance]. Z Gastroenterol 47: 758-769, 2009.

42. Rath T, Roderfeld M, Halwe JM, Tschuschner A, Roeb E and Graf J: Cellular sources of MMP-7, MMP-13 and MMP-28 in ulcerative colitis. Scand J Gastroenterol 45: 1186-1196, 2010. 